\title{
Equatorial cold-water tongue in the Late Ordovician
}

\author{
Jisuo Jin ${ }^{1}$, Renbin $\mathrm{Zhan}^{2,3}$, and Rongchang $\mathrm{Wu}^{2,3}$
}

${ }^{1}$ Department of Earth Sciences, University of Western Ontario, London, ON N6A5B7, Canada

${ }^{2}$ State Key Laboratory of Palaeobiology and Stratigraphy, Nanjing Institute of Geology and Palaeontology, Chinese Academy of Sciences, Nanjing 210008, China

${ }^{3}$ Center for Excellence in Life and Paleoenvironment, CAS, Nanjing 210008, China

\section{Data Repository including the Late Ordovician faunal lists, the geochemical data, and the Miaopo Formation, with one supplementary figure (Figure DR1) and two supplementary tables (Table DR1 and Table DR2).}

The four brachiopod faunas given below consist of examples of two cold/cool-water types (the Hirnantia fauna and the Foliomena fauna) and two warm-water types (the Saucrorthis fauna and the Sinorthis Fauna)

\section{The latest Ordovician Hirnantia fauna by tectonic plates and terranes}

(for a global summary see Rong and Harper, 1988)

\section{Avalonia}

MAA: The Hirnantian rocks in Maine, northeastern USA (Neuman, 1968): Hirnantia.

WUK: The Hirnantian rocks in southern Wales (Cocks and Price, 1975): Cliftonia, Dalmanella, Eostropheodonta, Hindella, Hirnantia, Leptaena, Skenidioides, Triplesia.

HWB: The Hirnantian rocks in Aber Hirnant, northern Wales (Temple, 1965): Dalmanella, Eostropheodonta, Hirnantia, Kinnella, Plectothyrella.

LDB: The Hirnantian rocks at Hol Beck, English Lake District (Temple, 1965): Dalmanella, Eostropheodonta, Hirnantia, Kinnella, Paromalomena, Plectothyrella.

EIL: The Hirnantian rocks in eastern Ireland (Wright, 1968): Cliftonia, Dalmanella, Eostropheodonta, Hindella, Hirnantia, Leptaenopoma, Plectothyrella.

\section{Baltica}


VSW: The Hirnantian rocks in Västergötland, Sweden (Bergström, 1968): Aphanomena, Cliftonia, Dalmanella, Draborthis, Dysprosorthis, Eostropheodonta, Hirnantia, Kinnella, Leptaena, Paromalomena, Plectothyrella.

ORN: The Hirnantian rocks in the Oslo region, Norway (Brenchley and Cocks, 1982):

Aphanomena, Cliftonia, Coolinia, Dalmanella, Draborthis, Dysprosorthis, Eostropheodonta, Hindella, Hirnantia, Kinnella, Leptaena, Leptaenopoma, Plectothyrella.

\section{Gondwana and peri-Gondawana}

POL: The Hirnantian rocks in Poland (Temple, 1965): Dalmanella, Eostropheodonta, Hirnantia, Kinnella, Paromalomena, Plectothyrella.

Bohemia (Marek and Havlíček, 1967): Aegiromena, Aphanomena, Cliftonia, Comatopoma, Dalmanella, Draborthis, Dysprosorthis, Eostropheodonta, Fardenia, Giraldibella, Hindella, Hirnantia, Kinnella, Leptaena, Leptaenopoma, Paromalomena, Plectothyrella, Rovozetina, Zygospira.

Morocco (Havlíček, 1971): Dalejina, Destombesium, Eostropheodonta, Hirnantia, Mirorthis, Plectothyrella, Undithyrella.

Algeria (Mergl, 1983): Plectothyrella.

West Libya (Havlíček and Massa, 1973): Eostropheodonta.

South Africa (Cocks et al., 1970): Arenorthis, Plectothyrella.

SHA: The Hirnantian rocks in San Huan Province, western Argentina (Benedetto, 1986):

Cliftonia, Coolinia, Dalmanella, Eostropheodonta, Hirnantia, Plectothyrella.

\section{South China}

WYH: The Kuanyinchiao Formation (Hirnantian) at Wangjiawan of northern Yichang, western Hubei, central China (Rong, 1979, 1984; Chen et al., 2000): Agiromena, Aphanomena, Cliftonia, Coolinia, Dalmanella, Draborthis, Dysprosorthis, Hindella, Hirnantia, Kinnella, Leptaenopoma, Mirorthis, Onychoplecia, Paromalomena, Plectothyrella, Skenidioides, Toxorthis, Triplesia, Trucitzetina.

SCS: The Kuanyinchiao Formation (Hirnantian) at Shuanghe of Changning, southern Sichuan, Southwest China (Rong, 1979; Li Guipeng et al., 2009): Aphanomena, Cliftonia, Dalmanella, Dorytreta, Draborthis, Hindella, Hirnantia, Kinnella, Mirorthis, 
Paromalomena, Plectothyrella, Sphenotreta, Toxorthis, Triplesia, Trucitzetina.

JZG: The Kuanyinchiao Formation (Hirnantian) at Jiadanwan of Zunyi, northern Guizhou, Southwest China (Rong, 1979, 1984): Fardenia, Hindella, Whitfieldella.

JCG: The Kuanyinchiao Formation (Hirnantian) at Jiancaohe of Zunyi, northern Guizhou, Southwest China (Rong, 1979): Aphanomena, Fardenia, Hindella, Hirnantia, Leptaena, Leptaenopoma, Paromalomena.

HTG: The Kuanyinchiao Formation (Hirnantian) at Honghuayuan of Tongzi, northern Guizhou, Southwest China (Rong, 1979; Chen et al., 2000): Aphanomena, Cliftonia, Dalmanella, Fardenia, Hindella, Hirnantia, Paromalomena, Plectothyrella.

LTG: The Kuanyinchiao Formation (Hirnantian) at Liangfengya of Tongzi, northern Guizhou, Southwest China (Rong, 1979, 1984): Aphanomena, Cliftonia, Dalmanella, Hindella, Hirnantia, Kinnella, Leptaenopoma, Plectothyrella.

HTG: The Kuanyinchiao Formation (Hirnantian) at Hanjiadian of Tongzi, northern Guizhou, Southwest China (Rong, 1979): Aphanomena, Cliftonia, Dalmanella, Hindella, Hirnantia, Kinnella, Leptaenopoma, Paromalomena, Plectothyrella.

GQC: The Kuanyinchiao Formation (Hirnantian) at Guanyinqiao of Qijiang, southern Chongqing, central China (Rong, 1979): Aphanomena, Cliftonia, Dalmanella, Hindella, Hirnantia, Paromalomena, Plectothyrella.

JAS: The Xinkailing Formation (Hirnantian) in Jinxian, southern Anhui, East China (Rong, 1979): Aegiromena, Fardenia, Paromalomena.

WJS: The Xinkailing Formation (Hirnantian) in Wuning, northwestern Jiangxi, East China (Rong, 1979): Aegiromena, Fardenia, Paromalomena.

NJS: The Xinkailing Formation (Hirnantian) in Nanjing, southwestern Jiangsu, East China (Rong, 1979): Aegiromena, Fardenia, Paromalomena.

\section{Sibumasu}

LBY: The base Jenhochiao Formation (Hirnantian) in Luxi, southwestern Yunnan, Southwest China (Rong and Sun, 1983): Aphanomena, Fardenia, Hindella, Hirnantia, Paromalomena, Plectothyrella.

NSM: The Kyaingtaung Formation (Hirnantian) in the Mandalay region, central Myanmar (Reed, 1915; recent field work, unpublished data): Dalmanella, Eostropheodonta, Fardenia, 
Hirnantia, Kinnella, Paromalomena, Plectothyrella.

Tibet

SZT: The Hirnantian rocks in Sinza, central Tibet, Southwest China (Rong and Xu, 1983): Aphanomena, Dysprorthis, Hirnantia, Kinnella, Paromalomena.

\section{Laurentia and peri-Laurentia}

PQC: The Hirnantian rocks in Percé, Quebec, Canada (Lespérance and Sheehan, 1976): Cliftonia, Dalmanella, Eostropheodonta, Hindella, Hirnantia, Kinnella.

AQC: The Ellis Bay Formation, Anticosti Island, Quebec, eastern Canada (Jin and Zhan, 2008; Copper et al., 2013): Aphenomena (= Eostropheodonta), Archaeochonetes, Barbarorthis, Becscia, Coolinia, Eochonetes (=Thaerodonta), Eospirigerina, Eostrophonella, Gnamptorhynchos, Hebertella, Hedstroemena, Hesperorthis, Hindella, Hirnantia, Hypsiptycha, Leptaena, Mendacella, Oanduporella, Onniella, Orthorhynchyllion, Parastrophinella, Plaesiomys, Ptychoplerella, Retrorcirostra, Rhynchotrema, Rostricellula, Siljanostrophia (= Platystrophia), Strophomena, Vellamo, Vinlandostrophia (= Platystrophia)

SUK: The Hirnantian rocks in Scotland (Harper, 1981): Eochonetes, Eopholidostrophia, Eospirigerina, Eostropheodonta, Fardenia, Glyptorthis, Hindella, Hirnantia, Hypsiptycha, Plaesiomys, Platystrophia, Rostricellula.

\section{Kazakhstan:}

KAZ: The Hirnantian rocks in Kazakhstan (Apollonov et al., 1980): Aegiromena, Aphanomena, Cliftonia, Dalmanella, Eostropheodonta, Fardenia, Hirnantia, Kozlowskites, Leptaena, Leptaenopoma, Paromalomena.

\section{The Late Ordovician Foliomena fauna by tectonic plates and terranes}

\section{Avalonia}

AP: Crugan Mudstone (late Katian), Afon Penfhos, Llyn Peninsula, North Wales (Cocks and 
Rong, 1988); Glyptorthis, Dedzetina, Leptestiina, Anisopleurella, Holtedahlina, Leptaena, Foliomena, Christiania, Eostropheodonta, Eopholidostrophia.

CL: Crugan Mudstone (middle Ashgill), Crugan Lane, Llyn Peninsula, North Wales (Cocks in Price, 1981); Orbiculoidea, Dedzetina, Leangella, Leptestiina, Anoptambonites?, Durranella?, Foliomena, Christiania, Eostropheodonta, Zygospira?.

MN: Pyle Mountain Argillite (late Katian), northeastern Maine, USA (Neuman, 1994); Acanthambonia?, Orbiculoidea?, Skenidioides, Dedzetina, Karlicium?, Leptestiina, Aegiromena?, Anoptambonites, Paromalomena, Foliomena, Christiania, Nubialba, Cyclospira.

SD: Punta S'Argiola Member, Domusnovas Formation (late Katian), Sardinia (Dom 1 locality), Italy (Villas et al., 2002); Glyptorthis, Jezercia, Skenidioides, Dedzetina, Draborthis?, Leangella, Leptestiina, Aegironetes?, Kozlowskites, Foliomena, Christiania, foliomenid, Cyclospira.

\section{Baltica}

SC: Jerrestad Mudstone (middle Katian), Scania, Sweden (Sheehan, 1973); Glyptorthis, Dolerorthis, Dedzetina, Heterorthina?, plectambonitoids, Leptestiina, Chonetoidea, Anoptambonites, Kozlowskites, Foliomena, Christiania, Cyclospira.

SW: Jonstorp Formation (middle Katian), Västergötland, Sweden (Sheehan, 1979); Leptestiina, Foliomena, Christiania.

VG: Ulunda Mudstone (late Katian), Västergötland, Sweden (Sheehan, 1979); Rugosowerbyella, Foliomena, Christiania.

\section{Peri-Gondwana}

BG: Loc. 74B 21 (late Katian), Central Belgium (Sheehan, 1987); Triplesia, Leangella?, Sowerbyella?, Foliomena.

LN: Pa Kae Formation (middle Katian), La Ngu District, Satun Province, southwest Thailand (Cocks and Fortey, 1990); Orbiculoidea, Foliomena, Christiania.

PR: Králův Dvưr Formation (late Katian), Prague, Czech Republic (Havlíček and Vanek, 1966); Dedzetina, Leptestiina, Kozlowskites, Foliomena, atrypid 2. 


\section{South China Plate}

BJ: Linhsiang Formation (middle Katian), Bijie, Guizhou Province, southwest China (Rong et al., 1994); Dedzetina?, Chonetoidea, Kassinella, Christiania.

BS: Pupiao Formation (middle Katian), Baoshan, Yunnan Province, southwestern China (Rong et al., 1999); Foliomena.

CN: Linhsiang Formation (middle Katian), Changning, Sichuan Province, southwestern China (Rong et al., 1999); Kassinella, Christiania.

FZ: Changwu Formation (late Katian), Fengzu, Jiangshan, Zhejiang Province, eastern China (Rong and Zhan, 1996); Foliomena, Cyclospira, atrypid, Eospirifer.

HC: S. clavifrons Bed (late Katian), Holy Cross Mountain, Poland (Cocks and Rong, 1988); Glyptorthis, Dedzetina, Leptestiina, Eoplectodonta, Foliomena, Christiania, Cyclospira.

HN: Huangnekang Formation (middle Katian), Huangnigang, Jiangshan, Zhejiang Province, East China (Cocks and Rong, 1988; this paper); Orbiculoidea, Leangella?, Anisopleurella, Foliomena, Christiania .

HX: Tangtou Formation (middle Katian), Hexian, Anhui Province, eastern China (Rong et al., 1999); Foliomena, Cyclospira.

JS: Linhsiang Formation (middle Katian), Jingshan, Hubei Province, central China (this paper); Plectoglossa, Schizotreta, Dedzetina, draboviid indet., Diambonioidea, Anisopleurella?, Hadroskolos, Jingshanella, Foliomena, Christiania, parastrophinid indet., Anazyga?, Cyclospira.

LX: Top part of Pingliang Formation (middle Katian), Longxian, Shaanxi Province, northwestern China (Rong and Zhan, 1996); Paracraniops, Dolerorthis, Glyptorthis, Skenidioides, Leangella, Leptestiina, Anisopleurella, Sowerbyella, Foliomena, Christiania, Leptaena, Nubialba, Eosotrophina, Cyclospira.

MX: Pagoda Formation (early-middle Katian), Mianxian, Shaanxi Province, northwestern China (Rong et al., 1999); Ottenbyella, Skenidioides, Dalmanella, Epitomyonia, Chonetoidea, Leangella, Anisopleurella, Eoplectodonta, Foliomena, Christiania, Nubialba, Cyclospira.

NG: Tangtou Formation (middle Katian), Ningguo, Anhui Province, eastern China (Cocks and Rong, 1988); Leptestiina, plectambonitoids, Foliomena, Christiania, Cyclospira.

NJ: Tangtou Formation (middle Katian), Nanjing, eastern China (Cocks and Rong, 1988); Philhedra?, Acrothele?, Dedzetina, Leptestiina, Durranella, Kozlowskites, Foliomena, 
Christiania, Parastrophinella?, Cyclospira.

TS: Changwu Formation (late Katian), Tanshi, Jiangshan, Zhejiang Province, eastern China

(Rong and Zhan, 1996); Skenidioides, Epitomyonia, Kassinella, Holtedahlina?, Foliomena, Eospirifer.

XZ: Xiazhen Formation (late Katian), Xiazhen, Yushan, Jiangxi Province, eastern China (Rong and Zhan, 1996); orthids, Epitomyonia, dalmanellid 2, Tashanomena, Foliomena, Altaethyrella, Antizygospira, Ovalospira, Eospirifer.

YC: Lower to middle part of Miaopo Formation (early Katian), Yichang, Hubei Province, central China (Rong et al., 1999); Dolerorthis, Glyptorthis, Skenidioides, Sulcatorthis, Dedzetina, Diambonioidea, Multiridgia, Leptellina, Bilobia, Eoplectodonta, Anisopleurella, Durranella, Kassinella, Leangella, Foliomena, Christiania.

YH: Linhsiang Formation (middle Katian), Yanhe, Guizhou Province, southwestern China (Cocks and Rong, 1988); Dedzetina, Aegiromena?, Kassinella, Foliomena, Christiania. ZY: Chientsaokou Formation (middle Katian), Zunyi, Guizhou Province, southwestern China (Rong et al., 1994); lingulid, Paterula, Orbiculoidea, Leptestiina, Kassinella, Kozlowskites, Foliomena, Christiania.

\section{Kazakhstan Terranes (Chingiz, Chu-Ili)}

CG: Middle part of the Akdombak Formation (middle Katian), Chingiz, Kazakhstan (Klenina et al., 1984); Orthambonites (= Sulevorthis, see Jaanusson and Bassett, 1993 ), Dolerorthis, Dedzetina, Leptellina, Diambonia, Anisopleurella, Kassinella, Eoplectodonta, Sowerbyella, Strophomena, Kjerulfina?, Foliomena, Christiania, Ovalospira.

CI: Top part of the Anderken Formation (early Katian), Chu-Ili Range, Kazakhstan (Popov et al., 2002); Chonetoidea, Anisopleurella, Kassinella, Olganbonites, Zhilgyzambonites, Foliomena.

\section{The Middle Ordovician Saucrorthis fauna and its coeval brachiopod faunas by tectonic plates and terranes}

\section{South China: Saucrorthis Fauna}

CZY: The Shitzupu Formation (Darriwilian) at Shizipu, Zunyi, Guizhou Province, SW China 
(the type locality of this formation) (Xu et al. 1974; Zhan and Jin 2005a): Aegironetes, Bellimurina, Gonambonites, Leptaena, Leptellina, Orthambonites, Peritritoechia, Platymena, Porambonites, Saucrorthis.

CTZ: The Shitzupu Formation (Darriwilian) at Honghuayuan, Tongzi County, northern Guizhou, SW China (Zhang et al. 1964 and primary identification on the material newly collected by the authors): Bellimurina, Clitambonites, Gonambonites, Leptellina, Leptestiina, Orthambonites, Parisorthis, Platymena, Porambonites, Protoskenidioides, Saucrorthis, Sowerbyella.

CWX: The Shitzupu Formation (Darriwilian) at Shizigou in the vicinity of Weixin county town, northeastern Yunnan Province, SW China (Zhan and Jin 2005a): Calyptolepta, Glyptorthis, Halirhachis, Leptellina, Leptestiina, Martellia, Nothorthis, Onniella, Peritritoechia, Porambonites, Protoskenidioides, Saucrorthis, Sulevorthis, Tritoechia

CWD: The Kuniutan Formation (Darriwilian) at Wudang, Guiyang, central Guizhou Province, SW China (Rong et al. 2005): Anomalorthis, Aporthophyla, Hemipronites, Leptellina, Leptestia, Orthambonites, Parisorthis, Saucrorthis, Yangtzeella

CCN: The Dashaba Formation (Darriwilian) at Shuanghe, southern Changning, southern Sichuan Province, SW China (Zhan and Jin 2005b): Calyptolepta, Glyptomena, Heteromena, Horderleyella, Leptastichidia, Longvillia, Maydenella, Nothorthis, Orthambonites, Paralenorthis, Parisorthis, Pentagomena, Phragmorthis, Saucrorthis, Tarfaya, Tritoechia, Yangtzeella

CNQ: The Siliangssu Formation (Darriwilian) of Ningqiang, southern Shaanxi Province (Fu 1982; Chen et al. 1995): Calyptolepta, Idiostrophia, Metorthis, Orthis, Paurorthis, Ptychoglyptus, Rafinesquina, Vellamo, Yangtzeella

CCK: The Houping Formation (Darriwilian) at Houping, Chengkou, northern Chongqing, central China (Zhu et al. 1977; Chen et al. 1995): Calyptolepta, Eodiorthelasma, Parisorthis, Phragmorthis, Saucrorthis, Schedophyla, Virgoria

\section{Sibumasu: Saucrorthis Fauna}

CBL: The Shihtien Formation (Darriwilian) at Laojianshan, Baoshan, western Yunnan, SW China (this paper): Antigonambonites, Atelelasmoidea, Calyptolepta, Dedzetina, Glyptomena, Glyptorthis, Horderleyella, Leptastichidia, Leptellina, Leptestiina, Martellia, 
Nicolella, Nothorthis, Orthambonites, Paralenorthis, Peritritoechia, Plectorthis,

Porambonites, Protoskenidioides, Saucrorthis, Strophomena, Sulcatorthis

BST: The Naungkangyi Group and its equivalents (Darriwilian) in northern Shan States,

Myanmar (Cocks and Zhan 1998; Zhan and Jin 2005a): Bekkerella, Bellimurina, Cyclospira,

Dirafinesquina, Glyptomena, Ishimia, Leptellina, Nicolella, Onniella, Plaesiomys, Porambonites, Saucrorthis, Skenidioides

\section{Northern Iran: Saucrorthis Fauna}

IDM: The lower Lashkarak Formation (Darriwilian) of the Alborz Mountains, northern Iran (Ghobadi Pour et al. 2011): Bastamorthis, Martellia, Saucrorthis, Semnanostrophia, Yangtzeella.

\section{Avalonia}

CAV: The unnamed Ordovician tuff (Darriwilian) in Virgin Arm, Newfoundland, eastern Canada (Neuman 1976): Acanthorthis, Ahtiella, Antigonambonites, Atelelasma, Bimuria, Calyptolepta, Camerella, Glypterina, Gonambonites, Guttasella, Ingria, Inversella, Jaanussonites, Orthambonites, Paurorthis, Plectorthis, Productorthis, Rugostrophia, Tritoechia, Virgoria

UKW: The Llanvirn and lower Llandeilo rocks (Darriwilian) of central-southern Wales, UK (Lockley and Williams 1981): Christiania, Corineorthis, Dalmanella, Gelidorthis, Glyptorthis, Hesperorthis, Horderleyella, Kullervo, Lingulella, Macrocoelia, Mcewanella, Murinella, Oxoplecia, Palaeoglossa, Parastrophinella, Paterula, Porambonites, Pseudolingula, Rostricellula, Salopina, Schizocrania, Schizotreta, Schmidtites, Skenidioides, Sowerbyella, Tissintia, Triplesia

CAN: The Table Head Group (Darriwilian) of Newfoundland, eastern Canada (Cooper 1956): Aporthophyla, Archaeorthis, Idiostrophia, Paralenorthis, Rhysostrophia, Trondorthis

\section{Baltica}

NOW: The Otta Conglomerate of Otta, southern Norway (Harper et al., 2008): Calyptolepta, Camerella, Orthis, Ottadalenites, Palaeoneumania, Palaeostrophia, Paralenorthis, Paurorthis, Platytoechia, Productorthis, Ptychoglyptus, Rutrumella, Tourmakeadia, 
Trondorthis, Valcourea

SWO: The top Volkhov-Kunda succession (upper Dapingian to Darriwilian) of O” land, southeastern Sweden (Rasmussen, 2005; Rasmussen, personal comm. 2013): Ahtiella, Antigonambonites, Apheoorthis, Clitambonites, Glyptambonites, Inversella, Lycophoria, Orthambonites, Pahlenella, Porambonites, Pseudocrania, Ukoa

EST: The Middle Ordovician (Kundan) at several localities of Estonia and southwestern Russia (Rasmussen 2005; Rasmussen et al. 2007; Rasmussen, personal comm., 2013): Ahtiella, Anchigonites, Antigonambonites, Apheoorthis, Apomatella, Calyptolepta, Camerella, Clitambonites, Cyrtonotella, Estlandia, Glossorthis, Glyptambonites, Glyptorthis, Gonambonites, Hemipronites, Ingria, Inversella, Iru, Lacunarites, Leptella, Lycophoria, Neumania, Nicolella, Nothorthis, Orthambonites, Orthis, Oslogonites, Palaeostrophia, Paurorthis, Platystrophia, Plectambonites, Porambonites, Prantlina, Productorthis, Progonambonites, Pseudocrania, Ranorthis, Raunites, Ujukella, Ukoa

\section{Southern Tibet}

CTJ: The Lower Formation of the Jiacun Group at Jiacun, Nylam, southern Tibet, SW China (Liu 1976, 1979): Aporthophyla, Aporthophylina, Diaphelasma, Glyptomena, Hemipronites, Nanambonites, Paralenorthis, Tritoechia, Xizangostrophia

\section{Kazakhstan Terranes}

KZC: The Uzunbulak Formation (Darriwilian) of the Chu-Ili mountains, southern Kazakhstan (Popov et al. 2001): Aporthophyla, Christiania, Leptellina, Martellia, Orthidium, Paralenorthis, Pomatotrema, Taphrodonta, Toquimia, Tritoechia, Yangtzeella

\section{Laurentia}

UST: The Lenoir Formation (Darriwilian) of Concord Quadrangle, Tennessee, eastern USA (Cooper, 1956): Ancistrorhyncha, Atelelasma, Dactylogonia, Dorytreta, Glyptorthis, Hesperorthis, Macrocoelia, Mimella, Multicostella, Onychoplecia, Ptychopleurella, Rostricellula, Sphenotreta, Stenocamara, Titanambonites, Valcourea

USN: The Copenhagen Formation (Darriwilian) of Antelope Valley, central Nevada, SW USA (Cooper 1956; Ross 1967, 1970, 1972; Ross and Shaw 1972): Aporthophyla, Archaeorthis, 
Desmorthis, Idiostrophia, Porambonites, Rhysostrophia, Shoshonorthis, Stenocamara, Syndielasma, Trondorthis

NWH: The Hølonda Limestone (lower Darriwilian) of the Trondheim District, Norway (Neuman and Bruton 1974, 1989): Aporthophyla, Archaeorthis, Bockelia, Chaloupskia, Idiostrophia, Orthambonites, Rhabdostrophia, Rhysostrophia, Stenocamara, Syndielasma, Trondorthis, Trontlandella, Vehnia

\section{Precordillera}

ARS: The San Juan Formation (Darriwilian) of southern Ja'chal, San Juan, western Argentina (Benedetto, 2001): Aporthophyla, Monorthis, Polytoechia

\section{Tasmania}

AUT: The Upper Karmberg Limestone Formation and the basal Cashions Creek Limestone Formation of the Florentine Valley, southern Tasmania, Australia (Laurie 1991): Apatomorpha, Aporthophyla, Lepidomena, Leptellina, Maydenella, Orthambonites, Ptychopleurella

\section{The Early and early Middle Ordovician Sinorthis fauna by tectonic plates and terranes}

\section{South China:}

DZG: The lower Meitan Formation (Floian) at Dajiaosi, Zunyi, northern Guizhou, Southwest China (Zhan and Jin, 2008): Anomaloglossa, Apatobolus, Desmorthis, Doloresella, Euorthisina, Leptella, Nereidella, Nocturnellia, Nothorthis, Palaeoglossa, Paralenorthis, Pseudomimella, Protoskenidioides, Punctolira, Schedophyla, Sinorthis, Tarfaya, Tritoechia, Xinanorthis, Yangtzeella.

SCS: The lower Daguanshan Formation (Floian) at Shuanghe, Changning County, southern Sichuan, Southwest China (Zhan et al., 2005): Desmorthis, Ectenoglossa, Lingulella, Nocturnellia, Orthambonites, Orthis, Palaeoglossa, Paralenorthis, Taphrorthis, Tritoechia, Westonia.

HTG: The lower Meitan Formation (Floian) at Honghuayuan, Tongzi, northern Guizhou, 
Southwest China (Zhan et al., 2005): Anchigonites, Apatobolus, Desmorthis, Euorthisina, Fenxiangella, Ferrobolus, Idiostrophia, Leptella, Lingulella, Nereidella, Nocturnellia, Nothorthis, Obolus, Orthis, Palaeoglossa, Paralenorthis, Pseudomimella, Pseudoporambonites, Punctolira, Schedophyla, Schmidites, Sinorthis, Stichotrophia, Tapharorhtis, Tarfaya, Tritoechia, Trondorthis, Xinanorthis, Yangtzeella

HCC: The lower Yingpan Formation (Floian) at Houping, Chengkou County, northern

Chongqing, central China (Zhan et al., 2005): Euorthisina, Nocturnellia, Notorthis, Obolus, Orthis, Protoskenidioides, Pseudomimella, Sinorthis, Tarfaya, Tritoechia

SYG: The lower Meitan Formation (Floian) at Shatuo, Yanhe County, northeastern Guizhou, Southwest China (Zhan et al., 2005): Anchigonites, Euorthisina, Fenxiangella, Leptella, Nereidella, Nocturnellia, Notorthis, Orthis, Protoskenidioides, Pseudomimella, Punctolira, Schedophyla, Sinorthis, Stichotrophia, Taphrorthis, Tarfaya, Trigonotrophia, Tritoechia, Xinanorthis, Yangtzeella

CYH: The lower Dawan Formation (Floian) at Chenjiahe, northern Yichang, western Hubei, central China (Zhan et al., 2007): Anchigonites, Conodiscus, Desmorthis, Elliptoglossa, Euorthisina, Fenxiangella, Leontiella, Leptella, Martellia, Nereidella, Nocturnellia, Notorthis, Paralenorthis, Palaeoglossa, Protoskenidioides, Pseudomimella, Punctolira, Schedophyla, Sinorthis, Stichotrophia, Syntrophina, Tarfaya, Tritoechia, Yangtzeella

\section{Tarim}

NHX: The Dongguashan Formation (upper Floian to Dapingian) at Nanshan, Hongshan Lake, Chalukou, southern Hotan County, Karakorum region, southwestern Xinjiang, Northwest China (Xu and Sun, 1998): Eodiorthelasma, Leptella, Martellia, Metorthis, Paurorthis, Pseudomimella, Punctolira, Schedophyla, Sinorthis, Tarfaya, Yangtzeella.

\section{Peri-Gondwana (southern Europe)}

LMF: The upper part of the M Bed (Dapingian) of the Landeyran river valley in Montagne Noire, southern France (Mélou, 1982): Aportophylla, Gonambonites, Hesperonomia, Ocorthis, Orthambonites, Paurorthis, Pleurorthis, Prantlina, Progonambonites, Ranorthis, Sinorthis. 


\section{Stable oxygen isotope data for the Ordovician succession of South China}

All the stable oxygen isotope analyses (except for the Hirnantian Kuanyinqiao Formation) were based conodont apatite (Table DR1). The conodont samples were processed by diluted, buffered acetic acid, and the residues were separated using heavy liquid (lithium polytungstate) following the techniques proposed by Jeppsson et al. (1999). Conodonts were picked from the heavy fraction under a binocular microscope. The conodont elements, weighted around 05-1.0 mg per sample, were dissolved by adding $0.5 \mathrm{ml} 2 \mathrm{M} \mathrm{HNO}_{3}$ and chemically converted to $\mathrm{Ag}_{3} \mathrm{PO}_{4}$ following the method described by Joachimski et al. (2009). Oxygen isotopes were measured on $\mathrm{CO}$ generated by reducing $\mathrm{Ag}_{3} \mathrm{PO}_{4}$ in a high-temperature conversion-elemental analyzer (TCEA) coupled online to a ThermoFisher Delta V Plus isotope ratio mass spectrometer. All oxygen isotope values are reported in \%o relative to VSMOW (Vienna Standard Mean Ocean Water). Accuracy and reproducibility have been monitored by multiple analysis of NBS120c and internal standards and laboratory prepared $\mathrm{Ag}_{3} \mathrm{PO}_{4}$ samples. The average oxygen isotope composition of standard NBS $120 \mathrm{c}$ was measured as $21.7 \% \%_{0} \pm 0.25 \%$ (1 SD).

Conodont fossils are rare in the Hirnatian Kuanyinchiao Formation and, therefore, the stable oxygen isotope analysis (Table DR2) was based on micrite bulk-rock samples. The rock samples were obtained using an electric drill with a drillbit of $2 \mathrm{~mm}$ in diameter. During extraction of fresh micrite samples, larger bioclasts and calcite veins in the rock matrix were avoided. Sample powders were reacted with $100 \% \mathrm{H}_{3} \mathrm{PO}_{4}$ at ca. $200 \mathrm{~s}$ at $72^{\circ} \mathrm{C}$ in a Kiel IV carbonate device connected to a MAT 253 mass spectrometer. The generated $\mathrm{CO}_{2}$ was used for analyzing the carbon and oxygen isotopes, calibated by the Chinese national standard (GBW04405 ) with a $\delta^{13} \mathrm{C}$ value of $0.57 \pm 0.03 \%$ (VPDB) and a $\delta^{18} \mathrm{O}$ of $-8.49 \pm 0.13 \%$ (VPDB) during the analysis. The analytical precision is beter than $0.08 \%$ for $\delta^{13} \mathrm{C}(\mathrm{VPDB})$ and $0.08 \%$ for $\delta^{18} \mathrm{O}$ (VPDB).

All the isotope analyses were carried out at the Laboratory of Geochemical Analysis, Nanjing Institute of Geology and Palaeontology, Chinese Academy of Science. 
Table DR1. Stable oxygen isotope data based conodont apatite from the Ordovician succession of South China. The following abbreviations are used in the table below: Conodont samples, 06sx, samples from the Gukongkou section, Hubei Province; HD, samples from the Hengdu section, Zhejiang Province; AFI samples from the Jieling section, Hubei Province. S.D., standard deviation; $n$, numbers of conodont samples.

\begin{tabular}{|c|c|c|c|c|c|c|}
\hline Stage & Formation & Conodont biozone & Sample & $\begin{array}{c}\delta^{18} \mathrm{O}_{\text {apatite }} \\
\text { (\%o } \\
\text { VSMOW) }\end{array}$ & S.D. & $\mathrm{n}$ \\
\hline \multirow{2}{*}{ Katian } & \multirow{2}{*}{ Pogoda } & \multirow{2}{*}{ Hamarodus brevirameus } & $06 \mathrm{sx}-337 \mathrm{a}$ & 16.6 & 0.4 & 2 \\
\hline & & & $06 s x-335 b$ & 17.1 & 0.2 & 2 \\
\hline \multirow{6}{*}{ Sandbian } & Miaopo & \multirow{6}{*}{ Pygodus anserinus } & AFI5034 & 17.4 & 0.3 & 3 \\
\hline & \multirow{5}{*}{ Yenwashan } & & HD-Y9 & 18.4 & 0.32 & 2 \\
\hline & & & HD-Y6 & 17.5 & 0.84 & 2 \\
\hline & & & HD-Y5 & 17.9 & 0 & 2 \\
\hline & & & HD-Y4 & 17.5 & 0.32 & 3 \\
\hline & & & HD-Y1 & 17.8 & 0.23 & 2 \\
\hline \multirow{4}{*}{ Darriwilian } & \multirow{3}{*}{ Kuniutan } & \multirow{2}{*}{ Pygodus serra } & AFI5030 & 17.1 & 0.2 & 2 \\
\hline & & & AFI5029 & 16.6 & 0.1 & 3 \\
\hline & & Lenodus variabilis & $06 s x-306$ & 17.0 & 0.6 & 3 \\
\hline & Hulo & Histiodella kristinae & HD-A25a & 17.0 & 0.57 & 4 \\
\hline \multirow{3}{*}{ Dapingian } & \multirow{5}{*}{ Dawan } & \multirow{2}{*}{ Baltoniodus navis } & $06 \mathrm{sx}-148$ & 16.8 & 0 & 3 \\
\hline & & & $06 s x-141 b$ & 16.7 & 0.5 & 3 \\
\hline & & Baltoniodus triangularis & 06sx-140i & 16.9 & 0.2 & 3 \\
\hline \multirow{6}{*}{ Floian } & & Oenikodus evae & 06sx-136a & 16.8 & 0.29 & 3 \\
\hline & & & $06 \mathrm{sx}-135 \mathrm{c}$ & 16.6 & 0.04 & 2 \\
\hline & \multirow{4}{*}{ Hunghuayuan } & \multirow{4}{*}{ Serratognathus diversus } & $06 \mathrm{sx}-133 \mathrm{a}$ & 16.1 & 0.21 & 3 \\
\hline & & & $06 \mathrm{sx}-131 \mathrm{a}$ & 16.4 & 0.21 & 3 \\
\hline & & & $06 s x-119 a$ & 16.1 & 0.27 & 4 \\
\hline & & & $06 \mathrm{sx}-118 \mathrm{~b}$ & 16.3 & 0.01 & 3 \\
\hline \multirow{7}{*}{ Tremadocian } & \multirow{4}{*}{ Fenhsiang } & \multirow{4}{*}{ Paltodus deltifer } & $06 \mathrm{sx}-115 \mathrm{e}$ & 16.0 & 0.30 & 5 \\
\hline & & & $06 s x-115 a$ & 15.8 & 0.07 & 4 \\
\hline & & & $06 \mathrm{sx}-113 \mathrm{~h}$ & 15.8 & 0.21 & 6 \\
\hline & & & $06 \mathrm{sx}-113 \mathrm{e}$ & 15.9 & 0.2 & 3 \\
\hline & \multirow{3}{*}{ Nantsinkuan Fm. } & Glyptoconus quadraplicatus & 06sx-105a & 15.0 & 0.13 & 2 \\
\hline & & \multirow{2}{*}{ Acanthodus lineatus } & $06 \mathrm{sx}-101 \mathrm{f}$ & 16.1 & 0.04 & 2 \\
\hline & & & $06 s x-101 c$ & 15.1 & 0.25 & 2 \\
\hline
\end{tabular}


Table DR2. Stable oxygen isotope data based bulk-rock micrite samples from Guanyinqiao Formation as the Kuanyinqiao section (CQG), Qijiang county, Chongqing province.

\begin{tabular}{|c|c|c|c|c|c|}
\hline Stage & Formation & Conodont biozone & Sample & $\begin{array}{c}\delta^{18} \mathrm{O} \\
(\% \mathrm{~V}-\mathrm{PDB})\end{array}$ & $\begin{array}{c}\delta^{18} \mathrm{O} \\
(\% \text { VSMOW) }\end{array}$ \\
\hline \multirow{5}{*}{ Hirnantian } & \multirow{5}{*}{ Kuanyinchiao } & \multirow{5}{*}{$\begin{array}{c}\text { Amorphognathus } \\
\text { ordovicicus }\end{array}$} & CQG-01 & -7.378 & 23.3 \\
\hline & & & CQG-02 & -8.279 & 22.4 \\
\hline & & & CQG-03 & -7.063 & 23.6 \\
\hline & & & CQG-04 & -9.823 & 20.8 \\
\hline & & & CQG-05 & -8.085 & 22.6 \\
\hline
\end{tabular}

\section{Hypoxia, oxygen-minimum zone, and black shale deposits on the Yangtze Platform}

An important aspect of the Eastern Equatorial Pacific Cold Tongue (EEP-CT, see main paper for details) is the occurrence of subpycnocline hypoxia and oxygen minimum zone (OMZ) because of the lack of deep vertical mixing of the water column by severe storms. This results in not only the cool temperature, but also reduced oxygenation, to the water mass in the middle to deep subtidal zones (Moffitt et al., 2015). Most of the Upper Ordovician formations on the Yangtze Platform were accumulated below fair-weather wave base (e.g., Zhan et al., 2016). Their coolwater carbonate facies and benthic faunas, therefore, may be explained by a paleoequatorial setting dominated by cool-current. The Yangtze Platform was an expansive epicontinental sea during the Ordovician, and would differ from the modern Galapagos Islands in the open ocean in having somewhat reduced connection with the open ocean currents, making the platform substrate more susceptible to poor oxygenation. Such nutrient-laden cool-water current (similar to that of the Galapagos Islands), coupled with episodic plankton blooms and eutrophication, would promote organic-rich deposits at moderate water depth on the Yangtze Platform. This may explain the increased occurrence of organic rich limestone and fossiliferous black shale in the Upper Ordovician, such as the Miaopo and Wufeng formations over much of the Yangtze Platform (for a summary see Zhan and Jin, 2007).

The highly fossiliferous black shale of the Miaopo Formation (lower Sandbian) is a geologically puzzling facies, marked by a diverse benthic shelly fauna, with abundant, relatively small-shelled brachiopods and trilobites, often co-occurring with graptolites. Both the fauna and 
the paleogeographic position suggest a moderate water depth on the Yangtze Platform. The fossiliferous organic shales occur sporadically in local sags, laterally grade into limestones of the top Shihtzupu Formation (Fig. DR1; see also Zhan and Jin, 2007). The enigmatic occurrence of rich and diverse shelly benthos in the Miaopo black shale can be interpreted as periodic establishment of benthic faunas under hypoxic conditions, interrupted by seasonal or episodic eutrophication events, when organic productivity overwhelmed the ecosystem, resulting in organic-rich deposits.

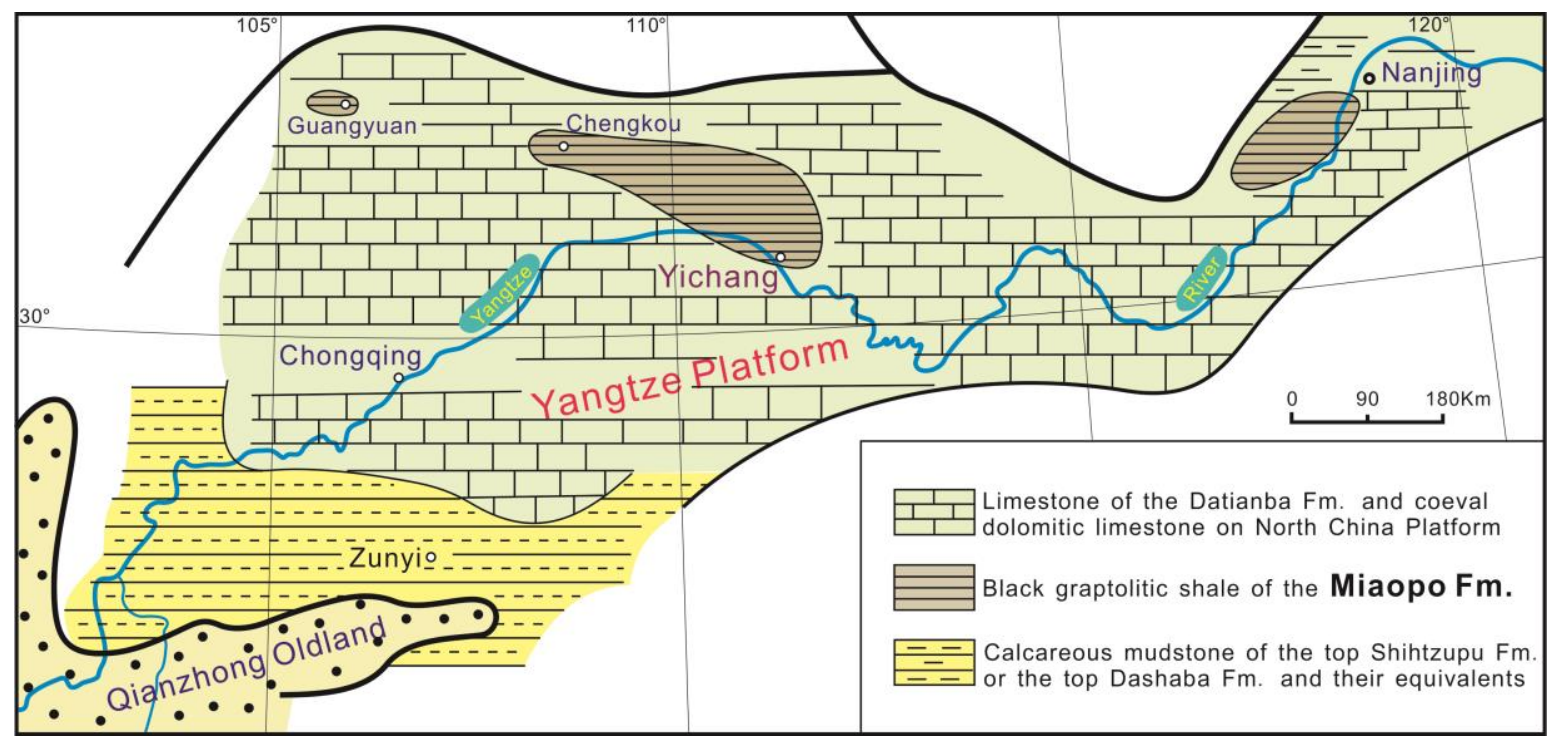

Figure DR1. Distribution of the fossiliferous black shale of the Miaopo Formation (lower Sandbian) on the Yangtze Platform.

The hypoxic depositional environment for the Miaopo Formation on the Yangtze Platform is interpreted here as the convergence of two major factors: First, South China drifted into the hurricane-free paleoequatorial latitude by the early Sandbian. The lack of hurricanegrade severe storms significantly reduced the wave disturbance base and vertical mixing of the water column in the Yangtze sea, making the substrate at moderate water depth susceptible to oxygen starvation, since severe storms would have facilitated oxygenation of the water column from about $15 \mathrm{~m}$ to $120 \mathrm{~m}$. Second, the paleogeographic position of South China during the Late Ordovician was similar to the Galapagos Islands today - the paleoequtorially located South China plate was some distance offshore west of the large Gondwana continent, which had a long coastal line stretching from the south polar region to the equator. This paleogeographic setting 
would have promoted cool-water upwelling to form an easterly equatorial cool-water current (Wilde, 1991; Pope and Read, 1997), similar to the East Pacific Humbolt cool-water equatorial current today (Karnauskas et al. 2007).

\section{References}

Apollonov, M.K., Bandaletov, S.M. and Nikitin, I.F., 1980, The Ordovician-Silurian Boundary in Kazakhstan. Alma-Ata, Nauka, 300 p.

Benedetto, J.L., 1986, The first typical Hirnantia Fauna from south America (San Juan Province, Argentine Precordillera): Biostratigraphie du Paleozoique, no. 4, p. 439-447.

Benedetto, J.L., 2001, Silicified early Ordovician (Srenig) brachiopods from the San Juan Limestone (Argentine Precordillera): Geologica et Palaeontologica, v. 35, p. 1-29.

Bergström, J., 1968, Upper Ordovician Brachiopods from Vastergotland, Sweden: Geologica et Palaeontologica, v. 2, p. 1-35.

Brenchley, P.J., and Cocks, L.R.M., 1982, Ecological associations in a regressive sequence: the latest Ordovician of the Oslo-Asker district, Norway: Palaeontology, v. 25, p. 783-815.

Chen, X., Zhang, Y., and Li, Y., 1995, Ordovician Basin analysis of China, in Cooper, J.C., Droser, M.L., and Finney, S.C., eds., Ordovician Odyssey. Fullerton: SEPM, p. 245-249. Chen Xu, Rong J., Mitchell, C.E., Harper, D.A.T., Fan, J., Zhan, R., Zhang, Y., Li, R., and Wang, Y., 2000, Late Ordovician to earliest Silurian graptolite and brachiopod zonation from Yangtze Region, South China with a global correlation: Geological Magazine, v. 137, p. $623-650$.

Cocks, L.R.M., Brunton, C.H.C., Rowell, A.J., and Rust, I.C., 1970, The first Lower Palaeozoic fauna proved from South Africa: Quaternary Journal of Geological Society of London, v. 125 , p. 583-603.

Cocks, L.R.M., and Fortey, R.A., 1990, Biogeography of Ordovician and Silurian faunas: Geological Society Memoir, v. 12, p. 97-104.

Cocks, L.R.M., and Price, D., 1975, The biostratigraphy of the Upper Ordovician and lower Silurian of southwest Dyfed, with comments on the Hirnantia fauna: Palaeontology, v. 18, p. $703-724$. 
Cocks, L.R.M., and Rong, J., 1988, A review of the Late Ordovician Foliomena brachiopod fauna with new data from China, Wales and Poland: Palaeontology, v. 31, p. 53-67.

Cocks, L.R.M., and Zhan, R., 1998, Caradoc brachiopods from the Shan States, Burma (Myanmar): Bulletin of the Natural History Museum London, v. 54, p. 109-130.

Cooper, G.A., 1956, Chazyan and related brachiopods: Smithsonian Miscellaneous Collections, v. 127(1), p. 1-1024; v. 127(2), p. 1025-1245.

Copper, P., Jin, J., and Desrochers, A., 2013, Ordovician-Silurian boundary (late KatianHirnantian) of western Anticosti Island: revised stratigraphy and benthic megafaunal correlations: Stratigraphy, v. 10, p. 213-227.

Fu, L., 1982, Brachiopoda, in Xian Institute of Geology and Mineral Resources, ed., Paleontological Atlas of Northwest China, Shaanxi-Gansu-Ningxia Volume, pt. 1: Precambrian and Early Paleozoic. Beijing, Geological Publishing House, p. 95-178. (in Chinese)

Ghobadi Pour, M., Popov, L.E., Kebria-Eezadeh, M.R., and Baars, C., 2011, Middle Ordovician (Darriwilian) brachiopods associated with the Neseuretus biofacies, eastern Alborz Mountains, Iran: Memoirs of the Association of Australasian Palaeontologists, v. 42, p. 263-283.

Harper, D.A.T., 1981, The stratigraphy and faunas of the Upper Ordovician High Mains Formation of the Girvan district: Scottish Journal of Geology, v. 17, p. 247-255. Harper, D.A.T., Bruton, D.L., and Rasmussen, C.M.Ø., 2008, The Otta brachiopod and trilobite fauna: palaeogeography of Early Palaeozoic terranes and biotas across Baltoscandia: Fossils and Strata, v. 54, p. 31-40.

Havlíček, V., 1971, Brachiopodes de l’Ordovicien du Maroc: Notes et Memoires du Service Géologique du Maroc, Rabat, v. 230, p. 1-135.

Havlíček, V., and Mass, D., 1973, Brachiopodes de l'Ordovicien supérieur de Libye occidentale: Implications stratigraphiques regionals: Géobios, v. 6, p. 267-290.

Havlíček, V., and Vanek, J., 1966, The biostratigraphy of the Ordovician of Bohemia: Sborník geologického Věd, v. 8, p. 7-67.

Jeppsson, L., Anehus, R., Fredholm, D., 1999, The optimal acetate buffered acetic acid technique for extracting phosphatic fossils: Journal of Paleontology, v. 73, p. 964-72. 
Jin J., and Zhan R., 2008, Late Ordovician orthide and billingsellide brachiopods from Anticosti Island, Eastern Canada: diversity change through mass extinction. Ottawa, NRC Research Press, $151 \mathrm{p}$.

Joachimski, M.M., Breisig, S., Buggisch, W., Talent, J.A., Mawson, R., Gereke, M., Morrow, J.M., Day, J., Weddige, K., 2009, Devonian climate and reef evolution: insights from oxygen isotopes in apatite: Earth and Planetary Science Letters, v. 284, p. 599-609.

Karnauskas, K.B., Murtugudde, R., and Busalacchi, A.J., 2007, The effect of the Galápagos Islands on the equatorial Pacific cold tongue: Journal of Physical Oceanography, v. 37, p. $1266-1281$.

Klenina, L.N., I.F. Nikitin, Popov, L.E., 1984. Brachiopods and biostratigraphy of the middle and Upper Ordovician of the Chinghiz ranges. Alma-Ata, Nauka, $196 \mathrm{p}$.

Laurie, J.R., 1991, Articulate brachiopods from the Ordovician and Lower Silurian of Tasmania: Association of Australasian Palaeontologists, Memoir, v. 11, p. 1-106.

Lespérance, P.J., and Sheehan, P.M., 1976, Brachiopods from the Hirnantian Stage (OrdovicianSilurian) at Percé, Quebec: Palaeontology, v. 19, p. 719-731.

Li, G., Zhan, R., and Wu, R., 2009, Response of Hirnantia Fauna to the environmental changes before the second phase of Late Ordovician mass extinction: Example from the Kuanyinchiao Formation at Shuanghe, southern Sichuan, southwest China: Geological Journal of China Universities, v. 15, p. 304-317. (in Chinese with English abstract)

Liu, D., 1976. Ordovician brachiopods from the Mount Jolmo Lungma region. In: Scientific Expedition Team to Tibet of the Chinese Academy of Sciences. A Report of Scientific Expeditions in the Mount Jolmo Lungma Region (1966-1968), Palaeontology (Fascicule 2). Beijing, Science Press, p. 139-158. (in Chinese)

Liu, D., 1979. New data of Ordovician brachiopods from the Mount Jolmo Lungma region, in Scientific Expedition Team to Tibet of the Chinese Academy of Sciences. A Report of Scientific Expeditions in the Mount Jolmo Lungma Region (1975), Geology. Beijing, Science Press, p. 71-74. (in Chinese)

Lockley, M.G., and Williams, A., 1981, Lower Ordovician Brachiopoda from mid and southwest Wales: Bulletin of the British Museum (Natural History), Geology, v. 35, 78 p.

Marek, L., and Havlíček, V., 1967, The articulate brachiopods of the Kosov Formation (Upper Ashgillian): Věstník Ústředního ústavu geologického, v. 42, p. 275-284. 
Mélou, M., 1982, Brachiopodes articulés, in Babin, C., Courtessole, R., Mélou M., Pillet, J., Vizcaino, D., and Yochelson, E.L., eds., Brachiopodes (articulés) et mollusques (bivalves, rostroconches, monoplacophores, gastropodes) de l'Ordovicien Inférieur (TremadocienArenigien) de la Montagne Noire (France Méridionale). Mémoire de la Société d'Études Scientifiques de 1'Aude, p. 23-35.

Moffitt, S.E., Moffitt, R.A., Sauthoff, W., Davis, C.V., Hewett, K., and Hill, T.M., 2015, paleoceanographic insights on recent oxygen minimum zone expansion: Lessons for modern oceanography: PLoS One, v. 10, p. e0115246, https://doi.org/10.1371/journal.pone.0115246.

Neuman, R.B., 1968, Paleogeographic implications of Ordovician shelly fossils in the Magog belt of the northern Appalachian region, in Zen, E.A., White, W.S., Hadley, J.B., and Thompson, J.B. Jr., eds., Studies of Appalachian Geology: New York, Interscience, p. 35-48.

Neuman, R.B., 1976, Early Ordovician (Late Arenig) brachiopods from Virgin Arm, New World Island, Newfoundland: Geological Survey of Canada Bulletin, v. 261, p. 11-61.

Neuman, R.B., 1994, Late Ordovician (Ashgillian) Foliomena fauna brachiopods from northeastern Maine: Journal of Paleontology, v. 68, p. 1218-1234.

Neuman, R.B., and Bruton, D.L., 1974, Early Middle Ordovician fossils from the Holønda Area, Trondheim Region, Norway: Norsk Geologisk Tidsskrift, v. 54, p. 69-115.

Neuman, R.B., and Bruton, D.L., 1989, Brachiopods and trilobites from the Ordovician Lower Hovin Group (Arenig/Llanvirn), Holonda area, Trongheim Region, Norway: new and revised taxa and palaeogeographic interpretation: Norges Geologiske Undersøkelse, Bulletin, v. 414, p. 49-89.

Pope, M.C. and Read, J.F., 1997, High-resolution stratigraphy of the Lexington Limestone (late Middle Ordovician), Kentucky, USA: A cool-water carbonate-clastic ramp in a tectonically active foreland basin, in James, N.P. and Clarke, J.A.D. (eds.), Cool-water carbonate: SEPM Special Publication, v. 56, p. 411-429.

Popov, L.E., Cocks, L.R.M., and Nikitin, I.F., 2002, Upper Ordovician brachiopods from the anderken Formation, Kazakhstan: their ecology and systematics: Bulletin of Natural History Museum London (Geology), v. 58, p. 13-79.

Popov, L.E., Vinn, O., and Nikitina, O.I., 2001, Brachiopods of the redefined family tritoechiidae from the Ordovician of Kazakhstan and South Urals: Geobios, v. 34, p. 131-155. 
Price, D., 1981, Ashgill trilobite faunas from the Llyn Peninsula, North Wales: Geological Journal, v. 16, p. 201-216.

Rasmussen, C.M.Ø., 2005, Middle Ordovician (Kundan) brachiopods from the East Baltic: aspects of taxonomy, biogeography, palaeoecology, bio- and ecostratigraphy: MSc thesis. Geological Museum, University of Copenhagen, Copenhagen. 149 p.

Rasmussen, C.M.Ø., Hansen, J., and Harper, D.A.T., 2007, Baltica: A mid Ordovician diversity hotspot: Historical Biology, v. 19, p. 255-261.

Reed, F.R.C., 1915, Supplementary Memoir on new Ordovician and Silurian fossils from the Northern Shan States: Palaeontologia Indica (new series), v. 6, p. 1-98.

Rong, J., 1979, The Hirnantia fauna of China with comments on the Ordovician-Silurian boundary: Journal of Stratigraphy, v. 3, p. 1-28. (in Chinese)

Rong, J., 1984, Brachiopods of latest Ordovician in the Yichang district, western Hubei, Central China: Stratigraphy and Palaeontology of Systemic Boundaries in China, v. 1, p. 111-176.

Rong J., and Harper, D.A.T., 1988, A global synthesis of the latest Ordovician Hirnantian brachiopod faunas: Transactions of Royal Society of Edinburgh, v. 79, p. 383-402.

Rong, J., and Sun, D., 1983, A latest Ordovician brachiopod fauna from Luxi, western Yunnan, S. China, in Papers for the Symposium on the Cambrian-Ordovician and Ordovician-Silurian boundaries: Nanjing, NIGPAS, p. 138.

Rong, J., and Xu, H., 1983, Terminal Ordovician Hirnantia fauna of the Xainza District, northern Xizang (N. Tibet), in Papers for the Symposium on the Cambrian-Ordovician and Ordovician-Silurian boundaries, Nanjing, NIGPAS, p. 139.

Rong, J., and Zhan, R., 1996, Distribution and ecological evolution of the Foliomena fauna (late Ordovician brachiopods), in Wang, H., and Wang, X., eds., Centennial Memorial Volume of Prof. Sun Yunzhu, Palaeontology and Stratigraphy: Beijing, China University of Geosciences Press, p. 90-97.

Rong, J., Harper, D.A.T., Zhan, R., and Li, R., 1994, Kassinella-Christiania associations in the early Ashgill Foliomena Brachiopod fauna of South China: Lethaia, v. 27, p. 19-28.

Rong, J., Zhan, R., and Harper, D.A.T., 1999, Late Ordovician (Caradoc-Ashgill) Brachiopod faunas with Foliomena based on data from China: Palaios, v. 14, p. 412-431.

Rong, J., Harper, D.A.T., Zhan, R., Huang, Y., and Cheng, J., 2005, Silicified rhynchonelliform 
brachiopods from the Kuniutan Formation (Darriwilian: Middle Ordovician), Guiyang, South China: Palaeontology, v. 48, p. 1211-1240.

Ross, R.J.Jr., 1970, Ordovician brachiopods, trilobites, and stratigraphy in eastern and central Nevada: United States Geological Survey Professional Paper, v. 639, p. 1-103.

Ross, R.J.Jr., 1967, Some Middle Ordovician brachiopods and trilobites from the Basin Ranges, western United States: United States Geological Survey Professional Paper, v. 523-D, p. 143.

Ross, R.J.Jr., 1972, Fossils from the Ordovician bioherm at Meiklejohn Peak, Nevada: United States Geological Survey Professional Paper, v. 685, p. 1-47.

Ross, R.J.Jr., and Shaw, F.C., 1972, Distribution of the Middle Ordovician Copenhagen Formation and its trilobites in Nevada: United States Geological Survey Professional Paper, v. 749 , p. $1-33$.

Sheehan, P.M., 1973, Brachiopods from the Jerrestad Mudstone (early Ashgillian, Ordovician) from a boring in southern Sweden: Geologica et Palaeontologica, v. 7, p. 59-76.

Sheehan, P.M., 1979, Swedish Late Ordovician marine benthic assemblages and their bearing on brachiopod zoogeography, in Gray, J., and Boucot, A.J., eds., Historical Biogeography, Plate Tectonics, and the Changing Environment: Proceedings of the Thirty-seventh Annual Biology Colloquium and Selected Papers: Corvallis, Oregon State University Press, p. 6173.

Sheehan, P. M., 1987, Late Ordovician (Ashgillian) brachiopods from the region of the Sambre and Meuse Ivers, Belgium: Bulletin de L'Institut Royal des Sciences Naturelles de Belgique, Sciences de La Terre, v. 57, p. 5-81.

Temple, J.T., 1965, Upper Ordovician brachiopods from Poland and Britain: Acta Palaeontologia Polonica, v. 10, p. 379-427.

Villas, E., Hammann, W., and Harper, D.A.T., 2002, Foliomena Fauna (Brachiopoda) from the Upper Ordovician of Sardinia: Palaeontology, v. 45, p. 267-295.

Wilde, P., 1991. Oceanography in the Ordovician, in Barnes, C.R. and Williams, S.H. (eds.), Advances in Ordovician Geology: Geological Survey of Canada Paper, v. 90-9, p. 283-298. Wright, A.D., 1968, The brachiopod Dicoelosia biloba (Linnaeus) and related species: Arkiv för Zoologi, Ser. 2, v. 20, p. 261-319.

Xu, H., and Sun, D., 1998, Discovery of Early Ordovician brachiopods of Yangtze Type in 
Karakorum region and its significance, in Chinese Academy of Science, ed., The Comprehensive Scientific Expedition to the Qinghai-Xizang-Kunlun Mountains, Palaeontology of the Karakorum-Kunlun mountain. Beijing, Science Press, p. 145-162. (in Chinese with English abstract)

Xu, H., Rong, J., and Liu, D., 1974, Ordovician brachiopods, in Nanjing Institute of Geology and Palaeontology, ed., Handbook of Stratigraphy and Palaeontology in Southwest China: Beijing, Science Press, p. 144-154. (in Chinese)

Zhan, R., and Jin, J., 2008, Diversity analysis of the Early Ordovician Sinorthis Fauna (Brachiopoda) from the Meitan Formation of Zunyi, northern Guizhou, South China, in Cusack, M., and Harper, D.A.T., eds., Brachiopod Research into the Third Mellennium in honour of the late Sir Alwyn Williams: Transactions of the Royal Society of Edinburgh: Earth and Environmental Science, v. 98, p. 239-251.

Zhan, R., and Jin, J., 2005, New data on the Foliomena fauna (Brachiopoda) from the Upper Ordovician of South China: Journal of Paleontology, v. 79, p. 669-685.

Zhan, R., Jin, J., and Chen P., 2007, Brachiopod diversification during the Early-Mid Ordovician: an example from the Dawan Formation, Yichang area, central China: Canadian Journal of Earth Sciences, v. 44, p. 9-24.

Zhan, R., Rong, J., Cheng, J., and Chen, P., 2005, Early-Middle Ordovician brachiopod diversification in South China: Science in China, Series D, Earth Sciences, v. 48, p. $662-$ 675.

Zhang, W., Xu, C., Xu, H., Wang, J., Lin, Y., and Chen, J., 1964, Silurian of northern Guizhou, in Nanjing Institute of Geology and Palaeontology, ed., Palaeozoic Rocks of Northern Guizhou: Nanjing, NIGPAS, p. 79-110. (in Chinese)

Zhu, Z., Ge, M., Xu, H., Yuan, K., Liu, Y., Li, Y., Su, L., He, T., Wang, Z., Li, X., Miao, Z., Ma, C., and Li, C., 1977, Early Palaeozoic rocks of Chengkou district, Sichuan Province: Stratigraphy and Palaeontology, v. 5, p. 1-64. 